\title{
THEORETICAL BASIS OF DEVELOPMENT OF LABOR MARKET AND SOCIAL POLICY IN THE REPUBLIC OF BULGARIA
}

\author{
Venelin Terziev \\ Academician of the Russian Academy of Natural History, Moscow, Russia, Prof. \\ D. Sc. (Ec.), D.Sc. (National Security), D.Sc. (Social Activities), Ph.D., National Military University, \\ Veliko Tarnovo, Bulgaria; University of Rousse, Rousse, Bulgaria, terziev@skmat.com
}

\begin{abstract}
The paper examines theoretical basis of labor market and social policy in connection to their development in conditions of the transition period in Bulgaria as a model containing common and specific features. The main characteristics and concepts of the labor market are discussed reflecting specific trends and explanations of the states of labor market. Labor market is scrutinized as a dynamic system and analyses and comparisons to other markets are made. Labor market policies on employment and unemployment are considered too as well as their importance in periods of economic and/or financial crises.
\end{abstract}

Keywords: social policy, labor demand, labor supply.

\section{INTRODUCTION}

The political changes of the early 90 -s of the twentieth century in Bulgaria lay the foundations for the development of a real labor market and major reforms in the hitherto existing social protection systems and the development of human capital. The transition from a centrally planned to a market economy in Bulgaria results in huge transformations in the ownership and structure of the national economy. These processes lead to a significant downturn in the functioning of the national economy. In these adverse economic conditions, the development of the labor market and social protection policies go through many turns due to the inconsistent policy of frequently changing governments and their different attitude towards policies on unemployment and employment.

The rapid economic reforms in the late 90-s give reason most economists and politicians to accept that the transition period has ended and a functioning market economy is present. Acquiring the features of a developed market economy, the national economy receives opportunities for more complete integration of the current global economic and social processes. At the same time the opportunities for participation in the common European and global networks, schemes, different initiatives by which the efforts to overcome the economic problems unite, expand. An access to new alternatives for innovative development of the social systems towards social inclusion, integration and cohesion, is also gained. 
The labor market is one of the markets of factors of production (along with the land market and the capital market). It is a specific mechanism for rational and efficient distribution and use of labor force for employment regulation. Economists use the term «labor market» as analytical tool in the search for answers to the questions: How to allocate income between individuals and households? Who determines the amount of payment for the work performed?

The labor market is of crucial importance for the stability of enterprises, for economic and social development of the country, for the standard and quality of life. The labor market, as one of the main markets, has an important role for the sustainable economic and social development of each country and region, the standard and quality of life of the population. Its development and situation have a direct influence on the development of the organizations and population. As one of the main markets, its development and status are determined by that of others, but the labor market itself has an impact on them in one way or another. The normal functioning of the economy, its dynamics, structure and efficiency determine the labor demand in volume but also in structure, as well as the possible cost of labor. In a market economy, the organizations find and provide themselves with resources, including also human resources, through the markets and in accordance with the rules, norms, institutions and the strategies and policies applied by them. The population, its income, professional and career development are carried out depending on the mechanisms regulating the labor market and the management of economic activity and social life.

There are various definitions of the labor market in the economic literature. The diversity of definitions is a result of the different perspectives the labor market is considered from:

- Spatial aspect: the labor market is the place where buyers and sellers of labor meet and carry out the purchase - sale of «labor» (the hiring of labor force);

- From an economic perspective: the labor market is the economic space where the persons seeking and offering work can meet and negotiate;

- From an institutional perspective: the labor market is a system of legal norms, principles, institutions and organizations that define and regulate the relationship between the persons seeking and offering work.

As an economic category, the labor market marks the combination of all economic relations that arise and take place in the interaction between hired employees and employers. The labor market is a place for meeting able-bodied persons in need of paid work and resource owners looking to hire labor force. Here they can conclude a sort of «a deal» between buyers and sellers of labor force, strengthened with the conclusion of an employment contract that regulates the working conditions, remuneration, working hours, holidays etc. The labor market is a special way to make contact between buyers and sellers of labor force.

The formation of the labor market requires the presence of:

- Physical persons who are willing to replace part of their free time for paid employment;

- Physical or legal persons who are looking to recruit labor force with relevant professional training and qualifications for a particular job;

- Institutional structure to mediate and regulate the relationship and interaction between persons seeking and offering labor force;

- A specific infrastructure that helps the employees and employers to realize their goals and interests.

The main characteristic of the labor market is related to the interaction between the supply and demand for work. The labor supply is the expressed will and ability of the able-bodied person to be hired at a certain level of remuneration and for a specified time. The aggregate labor supply is the sum of the individual supply and is determined by the number of able-bodied persons, the state of the economy, the labor productivity and work motivation. The labor demand is the expressed will and ability of the employer to hire a certain number of employees, who hold, in accordance with the requirements of the company, the necessary education and professional training. As in the demand for any other product, here should also be borne in mind that it is a question of solvent demand in terms of labor. This means that the employer assumes the responsibility and is able to pay an appropriate remuneration to its employees. The aggregate labor demand is the sum of the individual demand of all employers in the relevant labor market. The interaction of the two variables - the labor demand and the labor supply - determines the balance on the labor market. The competitive mechanism of this interaction is the one that determines the stability of the labor market. Main role in the coordination of the plans of the persons seeking and offering labor force plays the labor cost.

The economic process that takes place in the labor market affects the relationship between labor supply and demand in terms of content. On the one hand, this process starts with the search for job by the able-bodied 
person, and on the other hand, with the relevant activity of the employer - the company or organization. Once the two persons meet and negotiate the contractual terms of the employment, acceptable to both parties, an employment contract is entered. The service which the employee provides to the employer or the work itself is performed namely after the conclusion of the contract.

The labor market is often defined as a set of legal norms, principles, rules, requirements, procedures, institutions and policies that assists organizations to find the necessary labor force, and the able-bodied population to find the desired job (position). It is the abstract place where a market of the production factor «labor» is carried out, where «the transaction between buyers and sellers of labor» is carried out. It exists, when there is real demand and supply of labor and the cost of labor is determined by the ratio between them. It is a sort of mechanism for distribution of the labor force or the current economically active population, regulator of its motion, determines the level of employment and unemployment and determines the cost of different types of work.

When the unemployment is very high and creates a great social tension and significant human resources are not used, governments apply different policies to increase employment and / or to regulate the labor market. The last is related to the use of different measures and incentives, sometimes known as passive and/or active employment policy.

The passive policy on the labor market includes measures of the government on the payment of compensation and unemployment benefits, the establishment and functioning of the institutions of the labor market.

The active policy on the labor market includes measures, programs and plans aiming at getting the unemployed back to work, at their inclusion in the employment environment.

In case of high rate of unemployment and economic stagnation or crisis, when the demand for labor is low or insufficient, governments often use different programs and measures in order to create temporary jobs. They are directed mainly to the long-term unemployed. In the first place, programs that create employment in the public sector and / or in the various activities of general benefit to society (cleaning, afforestation, etc.) are used. In this case, the used concept «jobs in the field of socially useful activities» means jobs that are opened in the field of the typical municipal activities such as: public utilities, development of public services in the settlement and the industrial areas, maintenance and protection of municipal property, environmental protection, maintenance and protection of historical monuments and sites, etc. In the last twenty years, similar programs are also known in business activities and organizations of real business. These are the socalled subsidized programs or subsidized jobs. The inclusion of the unemployed in these programs is most often financed by the state budget (or other public resources) (providing basic salary, social insurance contributions to it, etc.). By these practically artificial job positions the unemployment reduces temporarily and the long-term unemployed are given the chance to return to employment (even for a limited period of time), income and social security. Such program in Bulgaria is the "From Social Assistance to Employment» program, which is in practice a system of private regional programs.

In the policies on unemployment regulation and employment increase an important place is assigned to increasing the capacity, the potential of the employed and unemployed by means of training, education and qualification upgrade. By definition, "professional qualification» is training for initial and additional qualification, as well as retraining of people of working age out of the educational system for adolescents.

The changes in employment and unemployment are also associated with the seasonality of production and many other activities that have a limited action during the year. The «seasonal work» concept is used for work that is performed during certain periods of the calendar year and is dependent on natural and climate conditions (construction, tourism, farming, etc.).

The opportunities to increase employment and consequently to reduce unemployment grow with the increase of flexibility of labor, with work with a lower duration in terms of working time and labor contracts used, etc. In connection with this, the "part-time employed person» indicator is used. It includes any person who works under an employment relationship with working time that is shorter than the legally established time for that job or profession.

The increase of the employment and the decrease of the unemployment are also possible by improving the activity and raising the entrepreneurial spirit of the working age population. Such form is self-employment, individual work of people, the so-called freelancers, craftspersons. The «self-employed» concept refers to any person who works individually or in partnership with other individuals on their own account.

Very often, the relationship between demand and supply of labor is mediated, carried out through different institutions (public or private). They carry out the socalled «Intermediary services» on the labor market, which 
include activities on information and employment of unemployed or employed persons seeking new job, as well as in organizing and conducting professional qualification.

In periods of economic and / or financial crisis, of financial or market difficulties of individual organizations, the latter proceed to reduction of their staff, insignificant, more significant or mass dismissal of employees. The concept of «mass dismissal» means the action as a result of which for a period of one month an employer terminates the employment contracts of a significant part of the staff (e.g. of more than 50 employees and officials for an enterprise with staff of more than 100 people, or of more than half of the employees of an enterprise with staff from 50 to 100 people).

A number of other concepts, that characterize the complex and dynamic processes in the labor market and in the employment sphere of the population, are also used.

\section{LABOR MARKET CONCEPTS}

There are a number of concepts that reflect specific trends and explanations of the state of the labor market. In this regard, we hereby present some basic concepts that can explain to some extent the changes in the main states and transitions on the labor market.

\section{THE CONCEPT OF THE NATURAL RATE OF UNEMPLOYMENT}

This concept is often considered as a version of the modern development of the neoclassical theory. Its basis is the microeconomic neoclassical marginal productivity theory, as a transition to macroeconomic model of explanation and analysis of unemployment is gradually conducted. That is why it is often associated with the monetarism and, of course, with its most typical representative, Milton Friedman (Volfgang, 1996a; Dulevski, 1992a).

According to the classical theory of marginal productivity, the employment in the company is appropriate until the moment when the marginal revenue of the labor product exceeds the marginal labor costs. If the payment is larger than the revenue, the employer conducts job cuts and terminates the employment. These job cuts will continue until the payment equals the marginal revenue from the labor product. Such equalization is obtained at the point of equilibrium of the relevant labor market.

In the concept of the natural rate of unemployment, an aggregation at macroeconomic level is conducted, assuming that all labor markets in the economy are in a state of equilibrium. It is characterized not so much by the level of nominal payment, but above all by the amount of actual payment. From here, it can be concluded that in equilibrium between all labor markets and the corresponding level of actual payment only one typical level of unemployment exists, which is defined as a natural rate of unemployment. According to this concept, if the level of actual payment remains above the equilibrium and a policy on reducing unemployment is conducted under these conditions, all this will lead to inflation. At the core of the concept of natural rate of unemployment lies the idea of the connection between actual salaries, unemployment rate and inflation. The natural rate of unemployment is therefore defined also as the only level that is compatible with the price stability. Under other equal conditions, the level of actual payment, balancing the labor markets, provides price stability, and the corresponding unemployment rate is defined as a natural extent of this phenomenon. Deviations of the actual level of unemployment from the natural are a result of the imbalance in the labor market.

The idea of the natural rate of unemployment is sometimes associated with the targets, set by many countries after the Second World War to reduce unemployment to its friction level. This also changes the perceptions of full employment of the labor force and implies a certain level of unemployment. That is why the supporters of this concept believe today that it is namely the natural level of unemployment that is the criterion of full employment, as we can see a convergence between the natural and frictional unemployment. The natural rate of unemployment, as determining the full employment, is subject to continuous dynamics in respect to the precise assessments. Today it is very difficult to offer adequate and secure methods for its precise assessment.

The concept of the natural rate of unemployment is another confirmation of the influence of the neoclassicism on the economic thinking and economic policy, when the inflation is actually a serious problem. Nevertheless, there is no country that does not target price stability. This is undoubtedly also related to the employment and unemployment policy that provides this stability.

\section{THE CONCEPT OF KEYNES FOR AGGREGATE DEMAND}

The examined versions of the neoclassical concept suggest that there are a sufficient number of job vacancies in the economy, which could be taken by the unemployed. The problem is only in the adaptation 
of the remuneration of these jobs to the level, clearing the labor markets. Here we do not discuss the lack of the required number of jobs that correspond to the number of job seekers. All the other conditions in the economy except for the level of payment are rather taken for permanent and corresponding to the given hypotheses. This is perhaps the biggest disadvantage of the neoclassicism, due to which it is often and reasonably subject to criticism.

The first serious blow against the dominant until the mid-30s neoclassical idea is struck by John Maynard Keynes. In his "General theory of employment, interest and money», Keynes simply destroys the idea of the imbalance in the labor markets as the main factor and reason for unemployment (Volfgang, 1996a; Dulevski, 1992a; Terziev, Arabska, 2014a). The facts and reality of the global crisis, which even simpler analysis is sufficient to be a counterpoint to the neoclassical idea, are of course in support and service of Keynes. That is why the large contribution of Keynes should be also considered in terms of time and objective circumstances that created sufficient conditions for challenging the dominant economic thinking by that time.

The main thesis of Keynes is that the insufficient demand does not provide the necessary number of jobs in the economy, regardless of the level of payment. Such situation does not encourage investments and opening of new job positions. Under the conditions of insufficient demand and lack of clear economic perspective, the owners of capital would prefer other forms of their investment, rather than investments and opening of job new job positions. In such global economic depression, the change of the interest rate has no significant impact on the investment intentions. Keynes denies the possibility of reviving the economy solely by adjusting prices and the amount of interest to the situation on the markets for commodities and capital. $\mathrm{He}$ sees the creation of stimulating conditions for the economic development in the rational use of other levers, such as taxes, expenditure and monetary policy. Fundamentally, this marks the beginning of a new era in the economic thinking. From that moment, the employment policy is more and more closely associated with the modern concept of managing demand.

If the holders of wealth have pessimistic expectations about the economic future and the change of prices and interest rates do not stimulate an increase in investment and production, the state should take economic intervention by macroeconomic policy of demand regulation. Thus, the macroeconomic stimulation will cause an increase in the aggregate demand, followed by increasing investments and production and eventually by increasing employment. This will logically lead to a reduction in unemployment.

This is in short the basic logic of the concept of Keynes, which becomes dominant in the economic thinking and policy since the mid-30s. Even the majority of economic levers for government are often associated with the Keynesianism. For example, many of the elements of the social payment that the neoclassicists object so strongly are considered appropriate mainly based on the Keynesian logic. Unemployment benefits, free food vouchers, medical care, employees' compensations, etc. are an addition to the inadequate consumption and contribute to a certain softening of the downward trend of the business cycle. Unlike the neoclassicists who support the flexible payment, Keynes stands for the idea of fixed salaries, without admitting their downward change.

It can be reasonably stated that several decades after Keynes many countries followed quite strictly his ideas in the form of official state employment policy. There were even significant changes in the legislation that were in line with the economic strategy. For a certain period, the results were quite encouraging, as the unemployment was really kept to a minimum. However, in the following decades the development of the unemployment has become a sobering indicator of the general enthusiasm of the Keynesian idea. This does not downgrade the Keynesian theory at all, but rather proves that every idea is adequate for a certain period of time and that the actual development is rather reflected in the constant changes.

A general conclusion can be made for the main differences between the neoclassical concepts and the concept of Keynes on unemployment. The main reason for unemployment according to the neoclassicists is the imbalance of the individual labor markets as a result of higher payment level than the one on the market. That is why they support the strategy of reducing the payment to clear the market, i.e. until reaching their equilibrium. For them, the mechanism of the labor market is identical with the mechanism of other markets. By assuming the flexibility of the social payment, the neoclassicists support the restrictive mechanisms for access to social protection and the need to reduce the level of its individual parameters. By supporting the idea of payment reduction, they do not pay great attention to the consequent reduction of the individual wellbeing and the possibilities for deformation in the distribution of income.

For Keynes the main reason for unemployment is rather the insufficient demand in the economy, than the imbalance in the labor markets. The regulation instruments are primarily the fiscal and monetary policies that have to create incentives for consumption, investment, production and employment. Here comes the question of the maintenance of the individual income and fixed payment. Keynes believes that the payment 
is not the primary lever for regulation, thus denying its reduction as a means of unemployment regulation. The reduction of payment leads to further stagnation in the demand and thus the problem of unemployment is multiplied.

In both models, deficiencies can be found when trying to apply them in their original form. For example, in the neoclassical model a specific level of payment should be established, which clears the market and put it in balance. The contradiction in the logic of such type of assessments is known as a critique of the Cambridge school. It consists of the impossibility to achieve an exogenous assessment of the equilibrium market level of payment, as it appears in the model as an endogenous quantity and reaches the problem of cyclicity.

This is the biggest problem in the Keynesian model. On the one hand, the optimal level of full employment is regarded as set and on that basis, the insufficient demand is proven. On the other hand, the model aims to reach the optimal level of employment using given variables. The problem of cyclicity appears again. In both models, the exogenous explanatory variable is absent. The neoclassical model does is present a way to accurately determine the equilibrium market level of payment. In the model of Keynes, there is no possibility for a precise assessment of the optimal level of full employment, respectively unemployment. In the absence of the necessary exogenous variables, the models create endogenous circulations with logical contradictions.

\section{THE CONCEPT OF STRUCTURAL UNEMPLOYMENT}

Keynes's ideas have found wide application in the macroeconomic policy on employment and unemployment. Perhaps until the end of the 60 s in most countries with developed market economy the dominant macroeconomic strategy is related primarily to demand stimulation. However, if up to the 50s the practical application of these ideas shows sufficiently satisfactory results in terms of the regulation of unemployment, in the 60 s and especially in the 70 s new previously unknown tendencies in the development of this phenomenon appear. For example, the creation of new job positions remains constant, but at the same time, the unemployment grows, and according to the model of Keynes, it should go down. A pronounced differentiation between the unemployment rates in the different population groups appears. Significant differences are observed in the different regions, which cannot be countered even by the increased mobility of the labor force.

While the employment is still strong in some groups of employees, in other groups the fluctuation of labor grows rapidly. Those who are affected more often by the unemployment appear to be young people, women and minorities. At the same time, the state continues to stimulate the effective demand and the opening of new job positions.

The objective economic reality already requires a new explanation of the phenomenon of unemployment and it comes in the form of the concept of structural unemployment. According to supporters of this concept, the increase of the unemployment in the 60 s and especially in the 70 s is a result of the structural changes in the economy. This is a period of an intense not only technical, but mostly technological rearmament and redistribution of the main capital in sectors and regions. The structural changes in the economy require new qualification of the employees in accordance with the level of the physical capital. However, it is available only for a certain part of the labor force, which is also characterized by high resistance to employment. The other part seems to have a limited educational and qualification background and is preferred by the employers under the new conditions. A structural unemployment appears as a result of the discrepancy between the qualification of the labor force and the demands of the physical capital. The main reason for the structural unemployment is considered primarily to be the technology that most developed countries have introduced in the 60 s and especially in the 70 s of the last century. Their historical development since the late 50 -s is characterized by a subsequent period in which the development of the physical capital is ahead of the development of the human capital. This leads to serious problems not only for the wage labor, but also for the efficient use of the capital. This development is also a lesson for the countries, which are on the path of market economy in connection with the risk of underestimating the human capital at the expense of the physical (Volfgang, 1996a; Dulevski, 1992a).

The critics of the concept of structural unemployment support the opinion that the technological changes primarily affect the additionally created job positions in the economy and cannot explain the general tendencies of employment and unemployment. The followers of the concept support the complex impact of the technological changes, which has led to significant changes and requirements to the alreadycreated job positions. They believe that the insufficient demand is now a less of a problem compared to the problem of the structural imbalance in the labor markets, which is why they do not accept the underlying macroeconomic policy for demand stimulation. The decrease of the unemployment in such situation can be 
achieved through intensive programs for training and retraining in order to adjust the structure of the labor force to the fixed capital. The structural discrepancy can be overcome by creating opportunities for greater labor mobility of the labor force. Therefore significant improvement of the information on job vacancies and their specifics, expansion of the capacity and possibilities of the labor offices and the other intermediate units, stimulating policy for redistribution of jobs, etc. are needed.

The concept of structural unemployment, like the Keynesianism, is reflected in the employment and unemployment policy. Furthermore, the two concepts lie in the basis of the combined approach of conducting such policy, which suggests that along with the stimulation of the aggregate demand an implementation of targeted programs for vocational training begins as well. Thus another concept of unemployment with an indisputable influence on the government policy shows up on the real economic scene in the late 50 s and especially in the 60 s.

\section{THE CONCEPT OF DUAL LABOR MARKET}

Each of the concepts of employment discussed here is interesting and largely backed with arguments, as it is a reflection of objective historical realities in the development of the economy and the labor markets. However, none of them gives a comprehensive and reliable response to the phenomenon of unemployment, without any substantive counterarguments. To be more precise, the concepts are logical enough in terms of explaining the phenomenon of unemployment, but only based on certain conditions and limitations, which often differ from the economic reality.

Another theoretical step is necessary to build a bridge between the undeniable logic of all previous concepts. This step is often associated with the concept of a dual labor market. It accepts the real existence of two separate and distinct labor markets. The labor force mobility is present in every one of them, but it is extremely limited between the two markets (Volfgang, 1996a; Dulevski, 1992a). The two main markets operate in a «dual economy» and are differentiated primarily based on two features:

The characteristics of the job positions;

The characteristics of the individual employees.

Today, they are known as primary and secondary labor market.

The primary sector or market operates on those principles, which are typical for the domestic labor market. It is characterized by better working conditions, higher payment and job security. Development is under the principle of internal promotion and protective barriers exist against the possibility of entering of labor force from the secondary sector or the foreign market. The employees admitted from the secondary sector in this market are usually low-skilled and take jobs only if there are no other candidates for them from the primary sector. The jobs in the primary labor market are highly demanding in terms of qualification of the labor force and at the same time create adequate conditions for its continuous improvement.

The secondary market is characterized by much lower qualification and skills requirements of the labor force. In addition, the opportunities for retraining that it provides are smaller and the turnover is very high. Usually the trade union influence is weak and the employers have sufficient market power to appoint or release employees, depending on their own interests. The labor discipline is generally lower than the one in the primary sector. As a result, the payment in the secondary sector is lower, there are worse working conditions, there is no employment guarantee, while the turnover is high. This is a market for low-skilled and mass work, which also develops certain employment discrimination. This is the market where the most discriminated demographic groups, such as young people, minorities and part of the female population, most often seek their livelihood.

The supporters of the concept of dual labor market offer a differentiated approach in the analysis and explanation of the unemployment in the two specific sectors or the labor market. For explanation of the unemployment in the primary market, the Keynesian concept of insufficient demand is most widely used. In the analysis of the unemployment in the secondary market, the concept of structural market imbalance is more widely used. Among the arguments here is the high turnover, as well as the highest rate of unemployment in low skilled or unskilled labor, etc. This allows the employers in the secondary market to pay relatively low salaries, as the people in the secondary market are more limited to find a job in the primary labor market.

The concept of dual labor market offers two main economic recipes to reduce unemployment under the characteristic duality of the markets. The first concerns the funding and promotion of public vocational training programs in order to acquire the necessary qualifications and skills of production by the employees in the secondary labor market. The second is associated with the state policy, conducted in order to alleviate 
the conditions and increase the possibility of transition from the secondary to the primary labor market. Depending on the specifics of both sectors, the concept also suggests the use of some of the main levers, typical for the Keynesian concept and the concept of structural unemployment.

\section{LABOR MARKET AS A DYNAMIC SYSTEM}

The labor market is a dynamic system in which the supply and demand for labor, hired people and employers interact. Main components of the labor market are the supply and demand for labor force, of labor; labor, labor force; labor cost; competition between demand and supply of labor. Subjects of the labor market are the employers and their representatives; the workers and employees and their representatives (professional and / or trade unions); the state and its authorities (the Ministry of Labor and Social Policy and its bodies - agencies, Directorates, etc. directly related to the labor market).

The labor supply is determined by the expressed will and ability to work of the able-bodied persons with certain quality characteristics over a certain period of time at an appropriate level of remuneration and other conditions. We can distinguish aggregate and individual labor supply. The first is determined by the number of able-bodied persons in the country, the economic development and its ability to create jobs, the level of education and vocational training, the level of remuneration, the existing mechanisms of taxation of the population, work motivation, etc. The individual labor supply is determined by the decisions of the household, its size and structure, the level of income and the spare time cost, the willingness of the individual for professional realization, self-affirmation and respect.

The labor demand is defined by the expressed will and ability of the employers to hire labor force with the appropriate quality and other characteristics, in accordance with the needs of the organization for newly established or a temporary jobs or positions. The aggregate labor demand is determined by the development of the economy, the business environment, the nature of the economic growth and the level of competitiveness and productivity, the level of remuneration, etc. Each employer, each organization determines individually its labor demand in accordance with the objectives and the strategy of its development, the level of efficient use of the already hired labor force, its investment and marketing strategy, financial situation, policy and investments in human resources, etc.

The institutions of the labor market are organizations, units or individuals which connect in one form or another those who seek labor force (the employers) and those who offer labor force (the able-bodied persons).

Labor force (the economically active population) are the persons at the age of 15 or older and over who invest or offer their labor to produce goods and services. This includes both the employed and unemployed. They are the main actors in the labor market and determine the size and structure of the labor supply.

There are different definitions of the terms "employed" and "unemployed". Some of them are commonly accepted within the International Labor Organization; others are used in the study of the labor market and population censuses, third are adopted in the system of public employment services. The accepted definitions determine the size and structure of the total employed, unemployed and economically inactive persons.

According to one of the definitions, employed are the persons (at the age of 15 or older) who work under an employment contract, are hired to do a certain job for remuneration or work independently in order to receive income in cash or kind.

Unemployed are the persons (at the age of 15 or older) who are able-bodied, do not work, do not receive income from employment, and are actively looking for work. According to the specific (special) legislation (Employment promotion act), unemployed person is any physically or mentally fit for work person who is not employed, not retired (for length of service and old age), is not included in professional training courses or any of the subsidized employment programs, is registered in the labor office by registered address (permanent or current address) and is actively looking for work.

The level (rate) of unemployment is measured and characterized by the economic activity. It is determined as the ratio between the number of unemployed persons and the economically active population. The larger the number of unemployed persons, the more reduced the economic potential, the country's labor force, limiting one of the most important resources. That is why the increase in employment is one of the most important goals in the macroeconomic policy of any government, as well as in the strategy of the European Union. Employment is characterized by rate (level) of employment, which is determined by the ratio between the number of employed persons and the number of people aged 15 and older. The increase in employment is associated primarily with the development of a competitive and efficient production, but also with an 
increased access to employment for all population groups, with a reduction of employment in the "gray» economy, economically inactive («discouraged» and others) and unemployed and mainly of the so-called «long-term unemployed persons», sometimes representing a considerable part of the unemployed persons. This group increases the «cost» of unemployment, leads to poverty, social isolation and other negative social trends.

Under the national legislation, long-term unemployed are the persons (unemployed) maintaining permanent unemployment registration in the labor offices for a period over 12 months. Analogical to it is also the indicator for average stay in unemployment, which characterizes the situation of the labor market, the degree of incompatibility between demand and supply of labor, in general and in the relevant labor markets.

One of the most important characteristics for the definition of the status of the unemployed person is that they are looking for employment and is ready to start working. For this purpose, the index "person who is actively looking for job» is used. As such is determined any person who visits employers in relation to employment, does not deny meetings with employers, organized by the public employment services (labor office).

The labor supply is generally directed to an appropriate job search. Under the current Employment promotion act in Bulgaria, an appropriate employment is the one that corresponds to the degree of education, training, health, gender, age of the person and is located in the same location or within a certain distance of it (for example at a distance of up to $30 \mathrm{~km}$ ), provided that there is suitable public transport. This definition of appropriate job is valid for the unemployed persons who are such to 12 months after this period, i.e. for the long-term unemployed - any job that corresponds to their state of health is deemed appropriate.

\section{LABOR MARKET PECULIARITIES}

The labor market is a specific market and despite its relative autonomy, it is similar in many aspects to both the factors and the product market. The relation of the labor market and its interaction with the product market (the market of goods and services) can be illustrated as follows. Households cause the demand for goods on the product market and the labor supply on the labor market. Business causes the supply of goods and the labor demand. The interaction of supply and demand on the market of the product markets determines the price level and production; the interaction between supply and demand on the labor market determines the level of payment and employment.

In many respects, however, the labor market is a specifically functioning market, which is different from other markets. The main reason lies in the nature and characteristics of the product that is demanded or supplied on the market - «the commodity» of labor. In the labor market, the employer comes to an agreement with the employee about the service that they wish to be performed. For the performed service, the employee receives a certain amount of money that is agreed in the process of negotiation. From here we can draw the conclusion that "the commodity" that the employee offers on the labor market is connected with their abilities and skills to work, thanks to which, under certain conditions, time and remuneration the performing of one service or another for the employer is possible. Therefore, what is bought and sold is the labor service, not the human capital. People's abilities, the human capital are inseparable part of the employee, i.e. of their owner. The specifics of the "commodity» that is «sold» on the labor market lies namely in that. Subject of the transaction, concluded on the market, is not the employee (the human capital), as this would mean their conversion into a commodity (as it was in the period of slavery), but their ability to work that the employer uses to achieve their objectives - income, profit. By providing their knowledge, skills, creativity, the individual provides at the same time a service to the employer for a certain price. In this sense, we can say that what is offered on the market are labor services. In the same sense, the concept of work is used hereinafter, i.e. in the meaning of labor service.

The labor demand also has its features that distinguish it from the demand for other goods. What is specific here is that the employer is not looking for a consumer disposable, but for a commodity as a production factor that is durable. That is why both the assessment of the condition of the current labor force and the assessment of its future development opportunities are important for them. The impact that the employee may have on the production efficiency and the results of it - the income and profit of the organization - is of great importance for the employer. The employer is not interested in the adaptability of the new employee, in their ability to join the team and their possible contribution to the development and enrichment of the corporate culture, for the improvement of the profile of the company, etc.

The duration of the labor relations is another feature that distinguishes the labor market from the other markets. As far as the employee is employed for a long period, the employer needs to invest in their training. In order not to suffer a loss from the return on invested funds, the employer aims to retain the employee as long as possible. The employee is also interested in the duration of the labor relations, as they get used to 
their obligations, to the team, the security and preferences provided by the company. This implies a greater opportunity for return on investment for increased productivity of higher skilled jobs for which they have contributed to (Volfgang, 1996a).

Differences between the labor market and other markets are also present in relation to the suitability of the preliminary information. For the employee they are expressed in the discrepancy between the previously agreed and the actual working conditions and remuneration. For the employer they consist in the discrepancy between the preliminary assessment of the qualities of the employee and the actual ones. This is one of the reasons for the application of probation, during which it may be assessed whether the preliminary agreed by the employer labor cost and the real labor cost match, and if necessary, the relevant adjustments are made.

Another feature of the labor market is the existence of organizations of employees and employers. When negotiating, the employee and the employer reach an agreement that is largely dependent on the balance of power of the trade unions and associations of employers. Unlike other markets, a specific legislation is typical for the labor market. Many of the clauses in the collective agreement are regulated and preliminary approved by the labor legislation: the working conditions and working hours, minimum salary, holidays, vacations, etc.

The labor market is under a strong state intervention by the implemented measures and programs under the active and passive policies. The state also intervenes in case of severe social problems on the labor market - low social security, labor discrimination, poverty, unhealthy labor conditions, etc. Most often, the social conflicts and tension in the country are related to problems on the labor market.

The above stated does not exhaust the specifics of the labor market, but still give a certain idea of its versatility and complexity. If we want to summarize, we should stress that all these specifics are interconnected with the nature and features of the specific «labor» commodity, i.e. with the object of the «purchase - sale» on the labor market (Bogdanova, 2018a; Bogdanova, 2017a; Bogdanova, 2016a; Bogdanova, 2015a; Bogdanova, 2011a; Terziev, Dimitrova, 2018b-d; Terziev, 2018e-i; Georgiev, 2016b; Terziev, 2018j-k).

\section{CONCLUSION}

The adequacy and the timeliness of the pursued policy are crucial for the effective support of the changes in the parameters of the labor market and for the economic development. The tracking of the delay of the effects and the changes in its duration should not be overlooked so that preventive measures for a timely response can be developed.

The shortening of the period in which the effects of the modern crisis are transferred to the labor market, respectively to the labor demand, reflects not only the degree of elasticity of the labor demand in relation to primary markets, but also the flexibility of the implemented policies. This fact brings in the focus of attention the flexibility of the labor markets and the opportunities (through its improvement) to enhance the mobility and the adaptability of the workforce to the rapidly changing labor demand.

Regulatory regimes have a certain influence on the development of the basic parameters of the labor market, but in general their impact, and that of specific policies in the labor market for the activation of the labor resources, for providing employment and a better labor adaptation of the workforce have effects with limited opportunities regarding the balancing of the demand and supply of labor (Terziev, Arabska, 2014a).

\section{REFERENCE LIST}

Volfgang, Frants. (1996a). Pazarat na truda, Sofiya, 1996 (Волфгганг, Франц. Пазарът на труда, София, 1996).

Dulevski, L. (1992a). Zaetost i pazar na truda, Sofiya, 1992 (Дулевски, Л. Заетост и пазар на труда, София, 1992).

Terziev, V., Arabska, E. (2014a). Assessment of active social policies' impacts on labor market in the Republic of Bulgaria // Sotsialyno-ekonomicheskie i pravovay razvitiyaekonomiki: kolektivnaya monografiya. - Ufa: Aeterna, 2014. - ISBN 978-5-906769-97-8 (Terziev, T., Arabska, E. Assessment 
of active social policies' impacts on labor market in the Republic of Bulgaria // Социальноэкономические и правовы развитияэкономики: колективная монография. - Уфа: Аэтерна, 2014. - ISBN 978-5-906769-97-8).

Bogdanova, Margarita. (2018a). Policies and Instruments for Social Development. // Journal of Innovations and Sustainability, Plovdiv, Bulgaria, 4, 2018, 1, pp. 59-63, ISSN 2367-8127 (CD-ROM), ISSN 23678151 (ON-LINE).

Bogdanova, Margarita. (2017a). Prilozhenie na prostranstveniya analiz v regionalnite izsledvaniya. // Statistikata kato nauka i praktika - traditsii i savremenni izmereniya: Sbornik s dokladi ot nauchnoprakticheska konferentsiya - Svishtov, 20 oktomvri 2017 g., Al Tsenov, 2017, str. 70-76, ISBN: 978954-23-1371-7 (Богданова, Маргарита. Приложение на пространствения анализ в регионалните изследвания. // Статистиката като наука и практика - традиции и съвременни измерения: Сборник с доклади от научно-практическа конференция - Свищов, 20 октомври 2017 г.АИ Ценов, 2017, стр. 70-76, ISBN: 978-954-23-1371-7).

Bogdanova, Margarita. (2016a). Tsentrovete za varhovi postizheniya i za kompetentnost - politiki i podhodi za upravlenie. // Sbornik dokladi ot Godishna universitetska nauchna konferentsiya: Nauchno napravlenie „Sotsialni, stopanski i pravni nauki“- Veliko Tarnovo, 20-21 oktomvri $2016 \mathrm{~g}$. Veliko Tarnovo, NVU - Izd. kompleks, 7, 2016, str. 38-56, ISSN 1314-1937 (Богданова, Маргарита. Центровете за върхови постижения и за компетентност - политики и подходи за управление. // Сборник доклади от Годишна университетска научна конференция: Научно направление "Социални, стопански и правни науки“ - Велико Търново, 20-21 октомври 2016г. Велико Търново, НВУ - Изд. комплекс , 7, 2016, стр. 38-56, ISSN 1314-1937).

Bogdanova, Margarita. (2015a). The stakeholders in the planning process - a network approach to analysis. // Evropeyski praktiki i natsionalni refleksii v planiraneto: Mezhdunarodna yubileyna nauchnoprakticheska konferentsiya: Sbornik s rezyumeta - Svishtov, 24-25 april 2015 g., Al Tsenov, 2015, str. 37-39, ISBN: 978-954-23-1058-7 (Bogdanova, Margarita. The stakeholders in the planning process - a network approach to analysis. // Европейски практики и национални рефрлексии в планирането: Международна юбилейна научно-практическа конференция: Сборник с резюмета - Свищов, 2425 април 2015 г., АИ Ценов, 2015, стр. 37-39, ISBN: 978-954-23-1058-7).

Bogdanova, Margarita. (2011a). Predizvikatelstva pred regionalnoto planirane v Balgariya. // Ikonomikata i upravlenieto $v$ XXI vek - resheniya za stabilnost i rastezh: Mezhdunarodna yubileyna nauchna konferentsiya - Svishtov, 8-9. noemvri 2011g.: Sbornik- dokladi, Al Tsenov, 2011, str. 282-286, ISBN: 978-954-23-0679-5 (Богданова, Маргарита. Предизвикателства пред регионалното планиране в България. // Икономиката и управлението в XXI век - решения за стабилност и растеж: Международна юбилейна научна конференция - Свищов, 8-9. ноември 2011г.: Сборникдоклади, АИ Ценов, 2011, стр. 282-286, ISBN: 978-954-23-0679-5).

Terziev, V., Dimitrova, P. (2018b). Concepts and models in social policy. // XIX International Scientific Conference Knowledge in practice (14 - 16 December, 2018, Bansko, Bulgaria), International journal scientific papers, IKM - Skopje, Macedonia, 28, 2018, 1, pp. 251-257, ISSN 1857-923X (for eversion), ISSN 2545 - 4439 (for printed version).

Terziev, V., Dimitrova, P. (2018c). Stages in social policy development. // XIX International Scientific Conference Knowledge in practice (14 - 16 December, 2018, Bansko, Bulgaria), International journal scientific papers, IKM - Skopje, Macedonia, 28, 2018, 1, pp. 265-271, ISSN 1857- 923X (for eversion), ISSN 2545 - 4439 (for printed version).

Terziev, V., Dimitrova, P. (2018d). Social policy development at the beginning of 21st century. // XIX International Scientific Conference Knowledge in practice (14 - 16 December, 2018, Bansko, Bulgaria), International journal scientific papers, IKM - Skopje, Macedonia, 28, 2018, 1, pp. 273-278, ISSN 1857- 923X (for e-version), ISSN 2545 - 4439 (for printed version).

Terziev, Venelin. (2018e). Importance of human resources to social development. // ADVED 2018- 4th International Conference on Advances in Education and Social Sciences Abstracts \& Proceedings, 1517 October 2018- Istanbul, Turkey, International Organization Center of Academic Research, www.ocerints.org, Istanbul, Turkey, 2018, pp. 204-212, ISBN: 978-605-82433-4-7.

Terziev, Venelin. (2018f). The active model of a social programme and its strategic advantage. // ADVED 2018- 4th International Conference on Advances in Education and Social Sciences Abstracts \& Proceedings, 15-17 October 2018- Istanbul, Turkey, International Organization Center of Academic Research, www.ocerints.org, Istanbul, Turkey, 2018, pp. 189-203, ISBN: 978-605-82433-4-7. 
Terziev, Venelin. (2018g). Active social programs development in Bulgaria: contemporary challenges and social management instruments. // ADVED 2018- 4th International Conference on Advances in Education and Social Sciences Abstracts \& Proceedings, 15-17 October 2018- Istanbul, Turkey, International Organization Center of Academic Research, www.ocerints.org, Istanbul, Turkey, 2018, pp. 149-163, ISBN: 978-605-82433-4-7.

Terziev, Venelin. (2018h). Social assistance services and integrated employment in Bulgaria. // ADVED 2018- 4th International Conference on Advances in Education and Social Sciences Abstracts \& Proceedings, 15-17 October 2018- Istanbul, Turkey, International Organization Center of Academic Research, www.ocerints.org, Istanbul, Turkey, 2018, pp. 164-177, ISBN: 978-605-82433-4-7.

Terziev, Venelin. (2018i). Impact of the labor market policies for ensuring employment. // ADVED 2018- 4th International Conference on Advances in Education and Social Sciences Abstracts \& Proceedings, 1517 October 2018- Istanbul, Turkey, International Organization Center of Academic Research, www.ocerints.org, Istanbul, Turkey, 2018, pp. 178-188, ISBN: 978-605-82433-4-7.

Georgiev, Marin. (2016b). Obshtestvenoto i ikonomichesko razvitie v konteksta na sotsialnite politiki. // Spisanie za nauka „Novo znanie“. Visshe Uchilishte po Agrobiznes i Razvitie na Regionite, 5, 2016, N 4, str. 26-41, (Online) ISSN 2367-4598 (Online), (Print) ISSN 1314-5703 (Георгиев, Марин.

Общественото и икономическо развитие в контекста на социалните политики. // Списание за наука „Ново знание“. Висше Училище по Агробизнес и Развитие на Регионите, 5, 2016, N 4, стр. 26-41, , (Online) ISSN 2367-4598 (Online), (Print) ISSN 1314-5703).

Terziev, Venelin. (2018j). Development of social policy as theory and practice in Bulgaria. // 3rd Central \& Eastern European LUMEN International Conference, New Approaches in Social and Humanistic Sciences NASHS 2017, Chisinau, Republic of Moldova, June 8-10, 2017, 2018, pp.493-504, ISSN (print): 2601 - 2510, ISSN (on-line): 2601 - 2529, ISSN-L: 2601 - 2510, ISBN: 978-1-910129-15-9.

Terziev, Venelin. (2018k). Modeling active social programs in Bulgaria through social entrepreneurship encouragement. // 3rd Central \& Eastern European LUMEN International Conference, New Approaches in Social and Humanistic Sciences NASHS 2017, Chisinau, Republic of Moldova, June 8-10, 2017, 2018, pp.505-516, ISSN (print): 2601 - 2510, ISSN (on-line): 2601 - 2529, ISSN-L: 2601 -2510 , ISBN: 978-1-910129-15-9. 